\title{
Historical tension between the holistic and dualistic view of man in the church
}

\begin{abstract}
Author:
Herm Zandman ${ }^{1}$

Affiliations:

${ }^{1}$ Theological Faculty

North-West University,

Potchefstroom Campus,

South Africa

Correspondence to:

Herm Zandman

Email:

hermzandman@bigpond.com

Postal Address:

25 Hay Terrace, Kongorong

5291, South Australia

Dates:

Received: 28 Feb. 2011

Accepted: 25 July 2011

Published: 02 Oct. 2012

How to cite this article:

Zandman, H., 2012,

'Historical tension between

the holistic and dualistic view

of man in the church', In die

Skriflig/In Luce Verbi 46(1),

Art. \#40, 8 pages.

http://dx.doi.org/10.4102/

ids.v46i1.40
\end{abstract}

C 2012. The Authors.

Licensee: AOSIS

OpenJournals. This work

is licensed under the

Creative Commons

Attribution License.
Dualism has continually plagued the Church, especially from the time when Greek philosophers articulated the dualistic view of man in an excellent, scholarly way. Even when the Reformers militated against this phenomenon theologically, it still dominated life in general and Christian living in particular. This article considered the historical tension between the holistic and dualistic view of man in the church. It strove to do this by setting forth certain examples from history, showing how the Church wrestled with this tension. Furthermore, the author attempted to point out in which way the dualistic view of man was damaging to godly living, and why a holistic view of man was conducive to life under God in an ethically meaningful manner.

Die historiese spanning tussen die holistiese en dualistiese beeld van die mens in die kerk. Dualisme het die Kerk nog altyd beinvloed, veral sedert die era toe Griekse filosowe die dualistiese siening van die mens op ' $n$ uitstekende akademiese wyse bekendgestel het. Selfs toe die Reformeerders teologies te velde getrek het teen hierdie fenomeen, het dit die lewe in die algemeen en die Christelike lewe in die besonder aangetas. Hierdie artikel oorweeg die historiese spanning tussen die holistiese en dualistiese sienings in die kerk. Sekere voorbeelde uit die geskiedenis sal voorgehou word ter illustrasie van hoe die Kerk met hierdie spanning geworstel het. Die outeur sal verder poog om aan te toon hoe die dualistiese siening van die mens skadelik is vir ' $n$ goddelike lewe, en waarom ' $n$ holistiese siening van die mens bevorderlik is vir ' $n$ eties betekenisvolle lewe onder God.

\section{Introduction}

At my first meeting with Prof. Vorster, we discussed the phenomenon of dualism in the church and he stated that dualism was indeed a serious problem, even today. Many, he stated, do not really appreciate how serious it really is. It is a privilege for me to contribute on this subject in celebration of my esteemed promoter's many years of Kingdom service.

By the mouth of Moses the Lord declares to His people (Dt 6:1-2):

Hear, O Israel: The LORD our God is one LORD: And thou shalt love the LORD thy God with all thine heart, and with all thy soul, and with all thy might.

The Apostle Paul beseeches God's people to present their bodies as a living sacrifice, holy and acceptable to God (Rm 12:1). The Christian is called in this life, whilst being in the body, to live to God's glory (cf. Jos 7:19; 1 Cor 10:31).

Scripture informs us that we should live as whole persons (Dt 6:1-2), with our whole being, in God's service. As John Murray puts it: 'Christian ethics is concerned with the manner of life or behaviour consonant with the Christian faith. This life is not ethereal mysticism; it is existential' (Murray 1976:174-175).

Throughout history, the Church of Christ has struggled in its strive to maintain a holistic view of man in his service to God. The main antagonist to this view of man has been - and continues to be (J.M. Vorster 2004, personal communication, April, Potchefstroom) - a dualistic view of man, the view that the body is inferior, a prison on earth, and the soul or mind is superior, but temporarily imprisoned in the body (Silversides 1998). This dualistic view is hinted at by Murray, with the remark about ethereal mysticism. Such a view has been thoroughly developed by Greek philosophers, and has affected the church. The Apostle Paul remonstrates severely with the Corinthians (1 Cor 15) as they have been influenced by Greek philosophy and have become convinced of the inferiority of the body (Silversides 1998).

This article strives to show the influence of dualism on Judeo-Christianity through the ages by way of various historical illustrations, and attempts to show in conclusion: 
- why dualism is not a view of man to be held in the church

- why it is important for the health of the Church of Christ to strive for a view of man in the context of Christian ethics (as defined by Murray 1976:174).

\section{Historical illustrations regarding the struggle with dualism Dualism and holism during Bible times}

Our starting point is the nation of Old Testament Israel. When the theocracy was established with particular laws and rules reflecting the premises of God, training closely followed the will of God when things went well, and tended to move away from the dictates of God when there was a general falling away from the moral laws of God. Where the practice was truly modelled on the Word of God, holistic training was faithfully applied. This training was aimed at developing the whole person, since God commanded that He be served with heart, soul, and might (Dt 6:5). Society in the theocracy of Israel was informed by a Scriptural understanding, and the people lived either in obedience or in disobedience to the standards set by the Word of God - and these standards exhorted holistic education from the heart, wholly committed (Cowie 1999:2). The whole person lived bodily on earth and, as such, the entire person was trained in the holistic sense.

Through the church father Hieronymus, who lived in Bethlehem for quite some time, it is known that according to a centuries-old custom, round stones of varying weights were deposited outside the gates for youngsters to practise distance throwing. Archery, javelin throwing (1 Sm 21) and an ancient form of 'hammer throw' may have been part of customary education. Swimming too could have been in the repertoire. Through the image of the judgement on Moab in Isaiah 25:11, the common acceptance of the ability to swim appears clear as the prophet declares, 'And He [the Lord] shall spread forth his hands in the midst of them, as he that swimmeth spreadeth forth his hands to swim.' Running too probably would have been practised with purpose. Jacob blesses his son Naphtali, using the imagery of 'a hind let loose' (Gn 49:21). A particular skill was required for what the runners were asked to do in 2 Samuel 15:1, running in front of the chariots and horses. It is a small wonder that the Roman historian Tacitus can write about the Jews that their bodies were healthy and strong, well able to cope with the rigours of life (Kugel 1970:7).

In the years 700-600 BC, the very militaristic Greek polis Sparta professed strong motivation for strictly goaloriented bodily training (Kramer \& Van Schagen 1967:45; Kugel 1970:7). Aristotle severely criticised this approach to education in Sparta, calling it coarse and uncouth in that it neglected the soul (Kramer \& Van Schagen 1967:45).

The Babylonians (approximately 600 BC) conquered Judah and, as was that nation's custom, scattered the defeated inhabitants all over the Babylonian Empire. This would ensure control and promote loss of national identity, thereby weakening the desire to start wars of independence. It was on account of this policy that some youths of Judah ended up at Nebuchadnezzar's court as likely candidates for training in the political brain trust that the king wanted to develop from amongst the very best in his empire.

Melzar, prince of eunuchs (Dn 1:10) - probably without having a philosophical awareness of it - was very concerned that Daniel and his friends should have healthy appearances. His insistence that they follow the lifestyle of King Nebuchadnezzar's training regime was deeply rooted. He knew that the functioning of the whole person, in terms of royal approval, depended on healthy living. He was reassured that the boys were doing well, when they looked well. The entire person had to exude vitality, sparkling eyes and healthy skin (Josephus 1974:270). Speedy in a personal interview (May 2003, Auckland) says the following:

From the scientific perspective, there are links now between stress, and negative emotions, and the immune system, and there are measurable parameters of your immunity in terms of antibody levels and high blood cells and hormone levels that are altered at stress that affect health negatively in terms of putting you at risk of certain disease and so on. So science is confirming that stress and negative emotion are actually bad for the health and there is a whole wealth of scientific literature that will say that.

Subsequently, this was checked out on the Internet and, indeed, much is being written on this subject (Smith \& Bryant 2011:213-217; Vollmer-Conna et al. 2010).

In fact, the modern health industry speaks powerfully to people's emotions in order to sell products and services to enhance physical health and beauty (checking on the number of health and fitness websites, worldwide close to five million were found). Whatever is being done physically by a person in terms of health and grooming, the health and/ or cosmetics and/or nutrition industry, approaches it with the fundamental slogan: Looking good equals feeling good. The physical body is intimately entwined with the other facets of what constitutes the person. Melzar was looking for personality qualities akin to those attributed to what we today would call 'well-rounded persons' (Josephus 1974:270). Thus the holistic approach dominates man's view for training at this point in history, albeit not with the biblical aim to function as a living sacrifice in God's service (Rm 12:1).

Upon the return from captivity, the children of Israel did not find a ready-made place. Ezra informs that the people were fully engaged in all kinds of service. They had to travel in arduous circumstances, keep religious feasts, organise themselves according to political, economic and religious spheres of activity. This resulted in the writing of the Mishnah or Second Law (adaptation from the Law of Moses) in which piety and zeal were seen to attach themselves to outward observance and study of the letter of the Law (Edersheim 2000:8, 158). The people had to build, fight in battle, and demonstrate political dexterity when it came to dealing with 
perturbed neighbouring nations. Indeed, anything less than the whole person, committed with all facilities, would not do.

\section{Syncretism of the Biblical and Greek view of Man: Dualism enters the Church in earnest}

Under Alexander the Great (356-323 BC) Greek influence started to infiltrate Jewish society and Jewish thinking. Alexander, himself a Macedonian, was a great admirer of Greek culture and vowed to spread it far and wide (De Bie 1978:101). Edersheim's observations are worthy to note here, as at this point the first encounter between Jewish and Hellenistic thought occurs. He basically points out the initial incompatibility between the two thought systems, or world views. He writes:

But the difference between the 'Grecians' and the 'Hebrews' was far deeper than merely of language, and extended to the whole direction of thought. There were mental influences at work in the Greek world from which, in the nature of things, it was impossible even for Jews to withdraw themselves. (Edersheim 2000:8, 158)

This observation spots a situation with consequences into the far reaches of history-still-to-unfold. It puts the finger on the fundamental problem of two world views in conflict, world views which the church at certain moments in history has tried to marry.

The Hebrew view of man was holistic: the whole of man was wonderfully created by God and was dedicated to God's service. Man had to serve God from the heart and, in doing so, had to approach everything in life from the heart. God would judge man's heart, man's essence. David states in Psalm 26:2, 'Examine me, O Lord, and prove me; try my reins and my heart.' Solomon declares that 'he gave his heart to know wisdom' (Ec 1:17). Throughout the Book Ecclesiastes, he determines the futility or usefulness of ethical approaches in life in terms of the heart. Jesus himself asks the scribes (Mk 2:8) when they question the rightness of his actions, 'Why reason ye these things in your hearts?' Blaize Pascal declared that 'the heart has its reasons of which reason knows nothing' (Brainyquote 2012). Furthermore, what is in the heart is known by the fruits (Mt 7:16), that is, by the measure of ethical application in life's circumstances, societal and relational.

The chasm between Hebrew and Greek world view approaches is so very clear: The Hebrew approach is always relational and holistic; the Greek approach is scientifically distant, dualistic with matter as the prison of the superior mind.

The very moment that the Israelites lost their unique Hebrew view, they yielded to the Greek one and the schizophrenic situation arose in which man was on the one hand deified, and yet, on the other hand, viewed as mere matter. Man would judge himself as god of all and, in the process would devalue himself to the level of flotsam on the tide of history. Far removed from God the Creator, the great nations of the past were well known for their acts of paedophilia, homosexuality and abortion (Gorman 1982:19-32; Tripp 1988:420-423). Again, it is probably correct to say that current Western society is not much different with its reverence for the sport hero and its disdain for the unborn and the elderly, its reduction of other human beings to consumables (Kimbrell 1993:228-231). Certainly, in parts of society, bodily training is very dominant, but it is dominant for the wrong reasons. It is dominant to empower the self, empower the nation, rather than setting forth the power of God in godly service.

The Greek philosophy, as it spread as a result of the conquests of Alexander the Great, was vastly different to the Hebrew view of man, in fact, it was in juxtaposition (Van Til 1932:vi, 14). Plato, considered one of the leading thinkers in Greece, was deeply influenced by Orphic-Pythagorean dualism. Pythagoras, nearly a hundred years earlier (ca. 500 BC), taught a cosmic dualism in which matter and form were two equal and independent ultimate principles. This led to a view of man with a dualism between mind and body. The mind or soul is of supreme importance, whilst the body exists merely as a vehicle to serve the soul. Plato also held to this dualistic view of man, reducing man's body to a vehicle of the soul or mind. The mind was considered highest and best because it enabled man to identify with God (Hoffecker \& Scott Smith 1986:25-26). According to Van Til, Plato's views may be taken as a fair sample of all anti-theistic speculation to the present day. Plato tried to interpret reality in terms of a mixture of temporal and eternal categories, thereby exhausting all antitheistic possibilities. Modern epistemology presents no more than variations on these themes (Van Til 1932:vi, 14).

The prevalent dualism confused society. On the one hand, man was seen as inferior - leading to a basement, on the other he was exalted for his physical pursuits - leading to hero worship. This paradoxical confusion led to moral excess in terms of ethical conduct. The Apostles militated against such inclinations to moral deprivation constantly (cf. 1 Cor 5:1; Eph 4:17-32; Col 2:4-18; 1 Th 3:4-6; 2 Tm 3; Ja 3).

Resultantly, this led to earnest Christians taking 'world flight,' a search for spiritual closeness with God and revulsion for things related to the physical. This view of society created the idea of super Christians in the church with regard to those martyrs who counted the body as nothing in order for the soul to be saved (Flinn 1987b). In this, Christianity was removed from the original Hebrew concept of man as holistic and married unwittingly to the dualistic, Greek concept. The problem with this choice on the part of well meaning Christians was that this isolationism ran counter to the Lord's dictum to be salt and light (Mt 5:13-14) and to be in the world, though not of it (Jn 17:15).

The Greek philosophers, as stated before, depreciated the material and the physical, posing a metaphysical dichotomy between spirit and flesh, rather than an ethical one, as Scripture intends. The motif is not exclusively Greek; it is a pagan theme that occurs over and over, and explains why monasticism and asceticism, a logical expression of such 
a world view, is found in many other religions. Hindus, Buddhists, the Jewish Essenes, the Gnostics, and the Pythagoreans were all ascetic (Flinn 1987a).

It is worth noting that the Christians lived in an environment where the leading Roman philosophers Cicero and Seneca loudly proclaimed that the body is an obstruction to the soul, a burden and punishment. This view dovetailed very well with that of Christendom of the day in which withdrawal from all that was worldly was regarded as holy (Kramer \& Van Schagen 1967:45). As an aside: in God's Providence, this withdrawal also had positive consequences where those in the monasteries would continue to copy Scripture, and preserve a Christian culture that was threatened by heathenism in society at large.

\section{In summary}

During the Old Testament era God's messengers held before God's people a view of man that was holistic. Faithful Jews engaged in training the next generation on that basis. Where there had been a falling away from God, pragmatism would generally still dictate that the physical being was cared for. In this pragmatic approach Israel would be in tune with the surrounding nations.

When Greek philosophers, notably Plato, started to articulate a dualistic view of man thoroughly, the holistic view as found in Scripture started to unravel. Greek thought increasingly infiltrated the believers' thinking (Edersheim 2000:8, 158). The Apostle Paul had a notable battle to fight in the church (1 Cor 15; 2 Tm 2:17-18) regarding a physical resurrection of the body and holy living in the body. The Apostles continually had to voice warnings against immoral living and exhort the young Christian church members during the New Testament period in history to present their bodies as living sacrifices to God (Rm 12:1).

\section{Medieval era: The conflicting views of Man continue}

With the Edict of Milan (313 AD) persecution of Christians effectively came to an end. In 380 AD Emperor Theodosius made Christianity the state religion and forbade the worship of idols. The Christians, especially those who held office in the church, were regarded as the spiritual elite of society. Such a perception of the church leaders perpetuated the dualistic mindset as a spiritually engaged person was seen as closer to God than someone who was engaged in more mundane pursuits.

Initially, the climate in the church in relation to the physical was very cautious at best, and outspokenly negative at worst. Augustine would go as far as to say that the body is to be kept healthy in order to serve the soul (Kugel 1970:7). Sensationdriven games in Rome and rough, degenerate Germanic expressions of physical training were grist on the mill of ascetically, other-worldly inclined leaders and trendsetters in the church (Kramer \& Van Schagen 1967:45). Education centred on religion and chastity.

In feudal Europe church leaders were often seen to have much political power and they were regularly seen to be more concerned with getting involved in life politically rather than spiritually. Consequently, the church gradually became more tolerant toward physical activity. Only when particular activities contravened Christian morals, direct prohibition could be forthcoming, for example, in the case of the fourth Lateran Council of 1215, when partaking in jousts was forbidden (Kugel 1970:7).

Various ball games were very popular, as seen on frescos, miniatures and in poetry, but especially and foremost from archives. Huizinga (2004) in his authoritative work Herfsttij der Middeleeuwen concluded that this era was not as sombre as is generally assumed (Anon 2012). The game of skittles actually met with hearty approval of the church as the knocking over of skittles symbolised annihilation of heathens, according to Grimm (Kramer \& Van Schagen 1967:45). Archery was encouraged from a military stance. King Edward III in England issued an ordinance in 1337 in which he forbade the practice of other sport in order to promote the art of archery (Kramer \& Van Schagen 1967:45)! However, dualism still generally ruled the day, as physical activities were tolerated for pragmatic purposes, not in the context of a soundly biblical view of man.

With the crusades between 1100 and 1300 people in Europe expanded their horizons. Learning began to revive in Western Europe during these centuries, with the growth of cities, the rise of commerce and revival of the classical learning of the Greeks. European scholars were most impressed, especially with Plato. Under the sponsorship of the Roman Church, teachers and pupils began to gather themselves together in organised groups to study his teachings along with Scripture. Most successful in combining Greek thought with Christian teaching was Thomas Aquinas (1225-1274). His scholarly products so impressed the Roman Catholic powers that they adopted Aquinas's Nature and/or Grace theology as their official teaching and forbade anyone to disagree. The church hoped that using logic and appealing to human reason would make the Scriptures understandable and, resultantly, the Christian faith acceptable to man.

With the crusades as catalysts, a new kind of person developed in Europe, notably in the cities, namely the burgher. $\mathrm{He}$ had discovered the world beyond his immediate existence, international trade began to flourish and the burgher became the prosperous backbone of society. He began to form guilds, which each had their own patron saint who, according to tradition, practised its particular branch of industry (Knight 2003). The guilds had their own sport culture, initially developed with the aim to protect the cities in which they existed. Exercises in archery, running, jumping, shot put, wrestling and dancing were some of the common activities (Ter Gouw 1871). 


\section{The Renaissance: Rebirth of Greek view of Man}

We notice that, gradually the feudal Middle Ages were taken over by a new era, known as the Renaissance (rebirth, notably of Greek ideas, generally said to cover history from approximately 1350-1600). The movement started in Italy where the new, wealthy middle class was dismayed with the poor scholarly situation the nation found itself in and where a longing developed for the great eras of the past, for example, the time of Greek and Roman dominance with its high-profile philosophical and other scholastic pursuits (Combee 1995:80-81). The traditional pattern of following leaders of the church was eroded little by little, until it could be said that a new type of inhabitant emerged: Renaissance man, typified by independence, a desire to think for himself, no longer to be dictated by the church, eager to display his talents in all fields of knowledge. This new self-assuredness caused an increased reliance on 'self', a moving away from the spiritual moorings provided by the church up to this point in time. Humanism, with man celebrating reason as the highest good, became increasingly prominent in society. Dualism received further impetus.

In terms of church affiliation, people increasingly started to question teachings, doubting metaphysical matters involved in a life of faith. The need to reason things out and come to understand them became the defining tenet of this era. That resulted in serious questioning of church clergy regarding professed teachings, and in a falling away from the church.

The church, though doctrinally questionable in many ways, was consistently known as the moral conscience of society, placing much value on insistence that the laity be pure in conduct. Once a certain humanistic segment of society shook loose from those expectations, the way opened to freer expression of self. It follows almost axiomatically that in expressing the 'self' more freely, sport and physical training gained prominence quickly. It appears from literature and art that such was indeed the case, as evidenced in writings of Montaigne (1533-1592), who in his Essais (1580), claims that, educationally speaking, one does not develop a body and a spirit, but a person! (in Kugel 1970:30). Also Rousseau (1712-1778) makes a strong case for his Emile to engage in serious physical exercises (in Kugel 1970:31-33). This almost incidental return to holism was driven by the utilitarian view so as to have man function competently in this world for the sake of society and himself.

\section{Reformation: Holistic theology, dualistic practice}

As the Roman Catholic Church lost credibility with those who wanted to think for themselves (making human reason the measure apart from the Bible) they were seriously disposed to leave the Church. Meanwhile, another group with the same credibility concern regarding teachings and practices of the Roman Church reacted in the opposite direction, crying out for church reform. Amongst the leaders of this reform movement were Martin Luther (1483-1546) Germany; Ulrich Zwingli (1484-1531) Switzerland; John
Calvin (1536-1564) France and Switzerland; and John Knox (1505-1572) Scotland. Eventually, their teachings comprised the three 'solas' of the Reformation: Sola Scriptura, Sola Fide, and Sola Gratia (Scripture alone, faith alone, grace alone). This went counter to everything the Roman Catholic Church professed (Scripture plus Papal decrees, faith and works, grace and human efforts).

The Reformers were very zealous in promoting education. The motivation for this was first and foremost that the people would be able to read the Bible for themselves. Less well known is the fact that Martin Luther agitated fiercely against the drab and sombre educational approaches in his part of the world (Germany). He compared the schools with hell and purgatory, insisting that such a climate of education is objectionable. He recommended that learning be made into a positive experience and insisted that the whole person be trained.

Despite these efforts, the Reformation is stigmatised by the notion that it bred aversion to physical exercising in school and society as it put so much emphasis on Bible teachings of chastity, the importance of the sound spiritual walk. Unwittingly perhaps, this caused a dualism in practice, if not in theoretical writings.

But mankind, in the Providence of God, had come at a fork in the road of history with the emergence of the Renaissance and Reformation. On account of these movements people increasingly learned to think independently of a ruling institution. This would lead to a holistic view of man as held by the Reformers, or a pronounced dualistic view held by humanists, for example, those who held to a world view in which the God of Scripture has no place.

\section{Age of reason: Dualism governs}

In terms of the dualism that had marred the development of man so much already up to this point in history, Descartes is the philosopher to consider more closely in this era (i.e. the 17 th century). His reasoning and his influence in particular guaranteed that physical training was deemed irrelevant. The influence of Descartes has been, and still is, enormous, if the time spent on his views in teachers' colleges and the philosophy faculties at universities is any indication. The rational deism, in which he distinguishes between the mind and body, is a touchstone of modern educational philosophy in the late 20th and early 21st century, as evidenced in the New Zealand Curriculum Framework (New Zealand Business Roundtable for the Education Forum 1994:156-166; O’Rourke 1993:8).

His legacy of dualism actually goes well beyond academia into everyday thinking with expressions such as: 'these players are prepared both mentally and physically,' and 'there is nothing wrong with your body; it's all in your mind,' 'mind over matter.' There is a prevailing tendency, even today, to attribute the leading role in what makes human beings function to the mind, notably where economic motivation drives society (Postman 1985:25-44). 
The view of Descartes regarding the human being sets forth the old dualism of Plato in a new formulation, in that the res cogitans ('a thinking thing') is disembodied, separate and distinct from any material thing such as a body (res extensa). Matter, the physical world, is ultimately devoid of any intrinsic sentience or feeling. Matter, the physical nature, is utterly distinct and separate from the mind, which holds sentience and subjectivity.

Descartes struggled with the problem of the connection between these two essences; the mode of mutual influence continued to remain a mystery. He provided a (tentative) answer tothis mysteryby assuming a miraculous, supernatural intervention by God via the human soul, located in the pineal gland (de Quincey 1999). In this reasoning he held that part of the blood was a subtle fluid that he called animal spirits. The animal spirits, he believed, came in contact with thinking substances in the brain and flowed out along channels of the nerves to animate the muscles and other parts of the body. Descartes acknowledged the existence of God, but saw him as the giant clockmaker who winds up the universe and then stands back to let it take its course (Catholic Encyclopedia n.d.) This concept, Deism, depersonalises God and makes him devoid of the emotional and spiritual relationality that Scripture is so emphatic about (cf. Dt 5:9; Mt 23:37).

As the reign of Louis XIV, 'the Sun King,' drew to a close in 1715, France entered what is known as the Age of Enlightenment. In reality, the Age of Enlightenment proved to be almost a new Dark Age for France. A blatant antiChristianity, openly boasting of its rejection of the Bible and disbelief in the deity of Christ, emerged on a large scale for the first time in the Modern Age (Combee 1995:80-81). Meaning and relevance of life were no longer sought in the objective anchor of the biblical world view, but rather sought in manmade reasoning, both past and present. Most important was an abiding faith in the power of reason.

With regard to the value that is put on the man created by this distant God, it is bound to follow that such a man is not seen as intrinsically valuable, because the image he bears in himself of such a God is rather poor and mechanically defined, just as the perception of God himself is poor and mechanically defined. Add onto this the evaluation of the superiority of the mind in the dualistic scheme, and the recipe is that much emphasis is placed on cerebral pursuits. This was exactly the scenario at the time of Descartes. The fact that the church was strongly influenced by this way of thinking as well is easily explained. Not all philosophical rationalism of this period was atheistic or antireligious, as evidenced in the world view espoused by Descartes. Deism was quite consistent with rationalistic presuppositions. It was logical, orderly, and systematic: a God set in motion an orderly universe and then He let it run according to natural laws. The discoveries of the Christian scientist, Isaac Newton (1642-1727), which were the result of rigorous application of mathematics, helped to reinforce the rationalist, Deist worldview.

The Romantic influence in the church came in a large portion through Friedrich Schleiermacher (1768-1834). Born in a
Pietistic family, he tried to reconcile his Christian convictions with the, to him, very attractive notions of Romanticism. His resultant theology was marked by the inner, individual experience. As such, the Scriptures became for Schleiermacher subordinate in authority to man's own intuition about God, religion, and truth. Man's only absolute truth comes, so he claimed, from his inner experience; objective theology does not exist. Reason was supplanted by subjective intuition. This fitted in exactly with the premise of Romanticism. The church and Romanticism held to common ground in that they both rejected truth based on supernatural, objectively rendered revelation. Sin, as a consequence, became a nonissue, Christ became merely a good example to follow. With such a view of God and man, essentially, self-expression became de rigueur.

Through the Renaissance, the Enlightenment and the Romantic era, man succeeded in pushing God further and further from the centre in terms of understanding reality. Man and nature are consistently at the centre. This phenomenon is as old as the desire expressed in the Garden of Eden at the moment of the fall into sin. When Adam and Eve committed their sin in the desire to 'be like God' they set the pattern for what man-without-God has tried to do ever since, for example blend in with nature. The very moment Eve took the fruit in order to be wise, she was already looking for self-initiated change apart from any reference to God. The yearning of the heart preceded the deed of the hand. The result was a desire on Adam and Eve's part to conceal their guilt by blending their identity into the background pattern of nature (Brooke 1997:178-180).

By approximately 1830 the Romantic era may be considered to have ended. The practical approach to life exemplified by German thinkers set a tone for utilitarian thrust. The flurry of discoveries in the field of natural sciences produced distinct pride in human self-sufficiency. The notions of the Romantic era were proven rather surreal and only led to chaos and tyranny respectively. People were suspicious of and disenchanted with any influential philosophy that was spouted. Ludwig Feuerbach (1804-1872) changed this and brought about a renewed interest in world view questions. He repudiated all romantic views of philosophy based on emotion. He claimed that any solution that seeks to go beyond the boundaries of nature and man is worthless. Arguing for a closed system, he denied the existence of the supernatural, very much in tune with ancient Greek naturalists. Man is merely part of nature, albeit the most perfect (!) part of it. From Feuerbach came the famous expression, 'Man is what he eats.' Death is the end of man, there is no point in daydreaming about eternity. In a closed system, man is also called upon to develop his own value system, since the universe is void of ethical character. We have now arrived at what has come to be known as the era of Modern Naturalism. This era is marked by a return to the ancient naturalism of the Greeks. It is a world view that influences all aspects of society and culture.

In science, this world view rested upon the conviction that the whole universe is not only composed of natural objects, 
but also shaped and directed by natural processes alone. Naturalistic thought in science reached its zenith in the 19th century with the work of Charles Darwin (1809-1882). Darwin taught that the world is always evolving, that this is done by way of steady, continuous processes, and that all life originates from non-life.

Darwin's theory of evolution was hailed as the big breakthrough regarding the origin of species. With theistic evolution an attempt was made to build a bridge between Darwinism and biblical teaching. To this day, in both secular and Christian circles, his teaching is believed in one form or another.

The view of man in such framework is not very exalting. It is hard to have respect for something brought forth by chance, which has no purpose for existence and is subject to the forces of nature beyond his control. We have now arrived at the point where the flight of Adam and Eve into the created world has caused man to express what Paul writes in Romans 1:32 regarding men who not only deny God, but have pleasure to do all those things that are accursed in God's eyes.

Man has put himself ontologically on the same level as all matter in the universe. Eventually, this will even lead to the situation where people walk around with 'pet rocks' and take their pet animals to church on Animal Day to receive the sacraments (Dorr n.d.).

The sense of sanctity for human life has been lost (abortion is now an accepted choice, euthanasia is making ground); a vague, general pantheistic awareness has created a closedenvironment self-preservation drive for all living, expressed in emotional outbursts over felled trees and other perceived ill-treatments of Gaia or 'Mother Earth'. Man has now moved from theism, through deism, to atheism and is destined to move from there into pantheism (everything is God) and panentheism (God is in everything).

The church does not provide God-centred answers with authority anymore in the era of Modern Naturalism. Where secularisation, the process whereby religious thinking, religious practices and religious institutions lose social significance (Hoffecker \& Scott Smith 1986:438-439) influences all of society, the church is affected as well. With the erosion of the authority of Scripture, the Bible becomes subordinate to human understanding, and faith becomes an empty word, or rather, the concept of faith shifts from the metaphysical-physical connection to the intra-physical understanding, for example, you have faith in a person's ability, in a product; faith is confined to the closed system of the material world exclusively.

The world view of man as held by the church is now eroded to a level where man is no longer the crown of creation, empowered under God, but rather a struggling living being which happens to be pretty far up on the evolutionary ladder, Jesus being a bit further than most (this view eventually also entered the conservative churches of the Reformation when Karl Barth introduced his theology of neo-orthodoxy in the mid-20th century).

\section{Summary of historic developments since the nascent of Greek philosophy}

Essentially, the church, which has to act as a covenant body with the uniqueness of individual members acknowledged and utilised for the good of that body (cf. 1 Cor 12), lost more and more the sense of doctrinal union with the Scripture as authority. Christianity became increasingly anthropocentric, tolerant of self-expression, man being the measure in matters of faith and everything resulting from such a position into other spheres of life. When the Greek philosopher Protagoras said, 'Man is the measure of all things', he certainly had the core of man's problem defined, restating the goal of our first parents in the Garden of Eden. The individuality thrust in the church was expressed in two opposite ways with essentially the same result: firstly, there was increased tolerance of what a personal believer would hold as true within the vested order of a denomination and, secondly, there was the movement of inter-denominationalism which basically made the statement that one could hold to any belief as long as the focus was on that which was held in common (since the late 20th century, the World Council of Churches is in intensive dialogue with other world religions trying to find common ground).

In such a climate, where the voice of the church has been weakened in the diversity of noises it produced, the voice of scriptural conscience has been reduced to comparatively small pockets of faithfulness amongst those who separated themselves from the mainstream in an effort to stay true to Scripture, society continued to foster individualism as normative. Expressions such as 'I am my own man,' 'you cannot tell me what to do,' grew in prominence as logical results from such a view of man.

\section{Conclusion}

Dualism is a view of man that has come into the church in a very well articulated manner via the Greek philosophers, Plato being the dominant one. Dualism distinguishes between matter and non-matter, mind - or soul - as superior, body - or the material - as inferior.

In terms of the gospel, the Apostle Paul remonstrates arduously with the believers (1 Cor 15:12-33; 2 Tm 2:17) about the bodily resurrection. Believers had bought into the Greek dualism and questioned the physical resurrection. The denial of Christ's resurrection will inevitably lead to disbelief in salvation and disbelief in the glory to come. This, consequently, will lead to a sense of futility regarding the need for godly living (1 Cor 15:32b). The Gnostics taught that the body is evil and the source of evil, and this would lead to either one of two responses:

- severe treatment of the body to subdue it, to bring it under, as was apparently the problem in Colossae (Col 2:20-23); this approach was also used by a Greek segment of society at the time, the Orphic sect

- abuse of the body through over indulgence (sexual immorality and consumerism), as was allegedly a problem 
in Corinth; the Greek group that lived this way in secular society at the time was the Dionysian sect.

In dualism only the soul is regarded as the real person. Paul literally calls the Corinthians to wake up out of a drunken stupor (1 Cor 15:34) and understand the doctrine that leads to godly living (Silversides 1998).

The error of dualism ultimately leads to a low view of man. It did so in Greek society, leading to all kinds of debauchery, it did so in Roman society (cf. Rm 1:18-32). It appears to lead to a confused view of man today, as we see on the one hand a world rife with pornography, abortion on demand, euthanasia, and on the other hand the celebration of life when a particular infant is brought into the world through a particularly complicated medical procedure.

The church has traditionally been the conscience of the nations (salt of the earth, light on a lamp stand - Mt 5:13-14), but it can only be so effectively with the right view of man, for example, as holistic and image bearer of God. Then man will have dignity and can justly demand to be treated with dignity by society at large.

Man has been wonderfully created (Ps 139:14-16) and is called upon to live for the glory of God as a whole person. Dualism leads to degeneration and subjective randomness as to what value to place on those whom God created as stewards under him (Belgic Confession Article XII).

\section{Acknowledgements Competing interests}

The author declares that he has no financial or personal relationship(s) which may have inappropriately influenced him in writing this article.

\section{References}

Anon, 2012, 'Middeleeuws Vermaak', viewed 09 August, 2012 from http://varenna. infoteur.nl/specials/middeleeuwen.html\#middeleeuws-vermaak

BrainyQuote, 'Pascal', viewed 12 July 2012, from http://www.brainyquote.com/ quotes/authors/b/blaise_pascal_5.html

Brooke, T., 1997, Virtual Gods, Harvest House Publishing, Eugene, OR.
Catholic Encyclopedia, n.d., 'René Descartes', viewed 09 August 2012, from http:// www.newadvent.org/cathen/04744b.htm

Combee, J.H., 1995, History of the World in Christian Perspective, A Beka Book, Pensacola.

Cowie, L.E., 1999, Leading the Lambs, Christchurch.

De Bie, J., 1978, Story of the Old World, The National Union of Christian Schools, Grand Rapids.

De Quincey, C., 1999, 'Radical Nature and the Paradox of Consciousness', viewed 12 November 2003, from http://www.ask.elibrary.com

Dorr, O., n.d., 'St. James Episcopal Church Pet Expo and Blessing of the Animals', viewed 09 August 2012, from http://www.stjamespcfl.org/specialservicesevents/ blessingoftheanimals.html

Edersheim, A., 2000, The Life and Times of Jesus the Messiah, Hendrickson Publishers, Inc., Peabody.

Flinn, R., 1987a, 'Monasticism', lecture presented at the University of Auckland, Auckland, 16 May.

Flinn, R., 1987b, 'Persecution and the Early Church', lecture presented at the University of Auckland, Auckland, 23 May.

Gorman, M.J., 1982, Abortion \& the Early Church, Intervarsity Press, Downers Grove.

Hoffecker, W.A. \& Scott Smith, G., 1986, Building a Christian Worldview, Presbyterian \& Reformed Publishing Company, Philipsburg.

Huizinga, J., 2004, Herfsttij der Middeleeuwen, Olympus, Amsterdam.

Josephus, F., 1974, The Works of Flavius Josephus, Baker Book House, Grand Rapids.

Kimbrell, A., 1993, The Human Body Shop, Harper Collins, London.

Knight, K., 2003, 'Guilds', viewed 08 November 2003, from http://www.newadvent. org/cathen/0766c.htm

Kramer, J.P. \& Van Schagen, K.H., 1967, Historisch Overzicht van de Lichamelijke Opvooeding, Nijgh \& Van Ditmar, 's Gravenhage-Rotterdam.

Kugel, J., 1970, Inleiding in the Geschiedenis van de Gymnastiek, Elinkwijk, Utrecht.

Murray, J., 1976, Collected Writings of John Murray: The Christian Ethic, The Banner of Truth Trust, Edinburgh.

New Zealand Business Roundtable for the Education Forum, 1994, Curriculum, Assessment and Qualifications: An evaluation of current reforms, Business Roundtable, Auckland.

O'Rourke, M., 1993, The New Zealand Curriculum Framework, Learning Media Ltd., Wellington.

Postman, N., 1985, Amusing Ourselves to Death, Penguin Books, New York.

Silversides, D., 1998, 'Doctrine, Hope, and Glory', viewed 12 July 2011, from http:// www.sermonaudio.com/sermoninfo.asp?SID=326058521

Smith, M.M. \& Bryant, J.L., 2011, 'Mind-body and mind-gut connection in inflammatory bowel disease', Gastroentological Nursing 25, 213-217, viewed 04 January 2011 from http://journals.lww.com/gastroenterologynursing/Abstract/2002/09000/ Mind_Body and Mind_Gut_Connection_in_Inflammatory.8.aspx

Ter Gouw, J., 1871, 'De Gilden', viewed 08 Aug 2011, from http://leende.dse.nl/pw/ geschiedenis/leendsegilden.html

Tripp, E., 1988, Classical Mythology, Collins, London.

Van Til, C., 1932, A Survey of Christian Epistemology, Presbyterian \& Reformed Publishing Company, Philipsburg.

Vollmer-Conna, U., Bennett B., Wakefield D., Hickie I. \& Lloyd A., 2010, 'The relationship between distress and the development of a primary immune response to a novel antigen', viewed 24 December 2010, from http://www. response to a novel antigen', viewed 24 December 2010,
sciencedirect.com/science/article/pii/S0889159103001077

Wood, D., 2003, 'A Mood Journal, Oppositional Defiant Disorder', viewed 29 December 2003, from http://leende.dse.nl/pw/geschiedenis/leendsegilden.html 